\title{
A Fuga da Donzela: Relações entre Mulheres, Violão e Discurso na Cultura Brasileira
}

\author{
Cláudia Araújo Garcia
}

Universidade do Estado de Minas Gerais | Brasil

\begin{abstract}
Resumo: Este artigo discute as associações entre a mulher e o violão a partir do discurso literário brasileiro, estabelecendo também um diálogo com o contexto cultural e a própria história do instrumento. Para isso, pesquisamos textos que abarcassem as interseçôes entre as mulheres e o violão, tanto sob a perspectiva da autoria feminina, quanto da escrita masculina. Percebemos, através das análises que, se por um lado, o violão revela a inquietude, a violação, e o desejo libertário da voz feminina; por outro, evidencia a reiteração de estereótipos vinculados ao espelhamento entre o corpo da mulher e o instrumento. Observamos também que, além da escassez de registros do violão em mãos femininas, prevalece um discurso que reforça o imaginário masculino, assim como não contempla a importância das mulheres violonistas ao longo da trajetória do instrumento.
\end{abstract}

Palavras-chave: Mulheres violonistas, Corpo feminino e violão, Violão na Literatura Brasileira, Representação, imagem e cultura.

\begin{abstract}
This article discusses the associations between women and the guitar based on the Brazilian literary discourse, also establishing a dialogue with the cultural context and the history of the instrument itself. For this, we searched for texts that included the intersections between women and the guitar, both from the perspective of female authorship and male writing. It was possible to perceive, through the analysis that, on the one hand, the guitar reveals restlessness, violation, and the libertarian desire of the female voice; on the other hand, it evidences the reiteration of stereotypes linked to the mirroring between the female body and the instrument. We also observed that, in addition to the scarcity of records of the guitar in female hands, a discourse that reinforces the male imagination prevails, as well as not considering the importance of female guitarists throughout the instrument's trajectory.
\end{abstract}

Keywords: Women guitarists, Female body and guitar, Guitar in Brazilian Literature, Representation, image and culture. 
associação entre a mulher e o violão se desdobra em questões, nem sempre pacíficas,
construídas e retratadas através do discurso. Historicamente, as mulheres violonistas
marcaram - pela importância e alcance - os caminhos seguidos pelo instrumento, porém, são bem menos numerosos os contextos e registros em que o violão aparece em mãos femininas. Em termos culturais, é possível perceber uma predominância da relação do violão com a esfera masculina, o que não estabelece propriamente questões hierárquicas ou de valor, mas, antes, nos coloca diante de importantes questionamentos sobre a escassez de registros e a forma com a qual se vincula a mulher e o instrumento.

Este, no entanto, não se trata de um caso isolado ou pontual, mas sim, do reflexo de um quadro mais amplo e geral da configuração estrutural e sistêmica da sociedade sexista. $\mathrm{Na}$ desigualdade de gêneros e no aporte ideológico patriarcal que molda as identidades e os papéis sociais, "os setores marginalizados, tal como o feminino, foram participantes ativos da história, mas submergiram muitas vezes no anonimato.” (TEDESCHI, 2015, p. 333).

De fato, a dominação masculina é um processo histórico, é resultado e ao mesmo tempo é produtor das relações sociais. Há, como identificado por Bourdieu (2003), a produção longa e contínua de processos que tornam inconscientes as estruturas históricas pelas quais surgiu e se consolidou a dominação masculina. (LORD, 2018, p. 131).

Não sendo um processo natural, mas uma construção histórica, a reiteração dos mecanismos de poder e privação, geram e impulsionam o apagamento da memória feminina. Neste sentido, Tedeschi (2015) esclarece que a memória é “culturalmente e coletivamente marcada por representaçôes de gênero" ao ser "produzida por sujeitos que determinam o que é ou não verdadeiro na cultura”, assim “o que não encontra sentido dentro desse quadro, ou se esquece, ou silencia-se [...].” (TEDESCHI, 2015, p. 335).

Estes mecanismos que estabelecem e reforçam as relações de poder e cerceamento social muitas vezes não perceptíveis no cotidiano ou naturalizados ao longo do tempo - operam através da linguagem e dos discursos (SCOTT, 2008). Com isso, a materialização da dominação fica exposta nos mais diversas campos, como é o caso da literatura brasileira. De acordo com Lord (2015) “essas visóes de mundo, que em síntese obedecem à dominação masculina, foram registradas na produção literária, tanto na construção das personagens quanto na liberdade ou proibição da autoria feminina.” 
(LORD, 2015, p. 133).

Isto também ocorre na esfera musical, pois nos espaços acadêmicos, nos programas de concerto, nos registros históricos, no repertório produzido e executado, e nos meios instituídos é possível perceber "os mecanismos de validação que excluem os trabalhos e os modos de produzir das mulheres" (ROSA; NOGUEIRA, 2015, p. 48) com os quais lidamos constantemente. No terreno das atividades consideradas pertencentes ao feminino, identifica-se uma cesura na percepção relacionada às mulheres instrumentistas, improvisadoras, compositoras ou intelectuais, em contraposição às professoras ou cantoras, mais aceitas neste ideal de feminilidade. Tal diferença ocorreria porque

As atividades que aproximam o fazer feminino ao trabalho intelectual são consideradas
transgressoras a este modelo e sofrem puniçóes veladas e explícitas, calcadas na
desconsideração e menos valia do trabalho, tácitas e aplicadas a priori, onde a vinculação ao
gênero determina o juízo de valor sobre o produto musical. (ROSA; NOGUEIRA, 2015,
p. 50-51).

Ao propormos como tema as relações entre as mulheres, o violão e os discursos, pretendemos percorrer alguns espaços possíveis desta "ampla rede de metáforas e práticas culturais associadas ao masculino ou ao feminino" (ROSA; NOGUEIRA, 2015, p. 48) que sustentam o sistema das relaçóes de gênero. Ao revisarmos os enunciados e valores aceitos, colocamos em discussão tanto a ausência de protagonismo feminino - que "é uma realidade tão presente que passa a ter status de uma suposta condição de normalidade" (ROSA; NOGUEIRA, 2015, p. 48), quanto algumas das narrativas já naturalizadas, reproduzidas e institucionalizadas.

Se, por um lado, o violão que encanta e seduz, comumente atua como representação da mulher, por outro, ele assume, no discurso feminino, o aspecto da violação, do roubo e do abandono. Além desta perspectiva, abordamos também, neste trabalho, a recorrente associação do violão ao corpo da mulher, em um discurso que objetifica e reforça determinados estereótipos e comportamentos. Por fim, observamos não só a reiteração das narrativas dominantes e a escassa presença do violão em mãos femininas no contexto literário brasileiro, como também percebemos um descompasso e, por vezes, um apagamento da mulher efetivamente tocando o instrumento. Apesar de deslocadas dos papéis passivos e da importância feminina para o instrumento, as mulheres violonistas, permanecem, muitas vezes, à margem. 


\section{1. "Não lhe ouças, filha, o canto merencóreo! / Fecha a janela e foge"}

No campo dos estudos comparados, ao pesquisarmos o violão (e os instrumentos a ele correlatos) na poesia brasileira foi possível constatar tanto a predominância dos pontos de contato com esfera masculina, quanto a raridade de contextos em que o instrumento aparece sendo tocado por uma mulher (GARCIA, 2019).

Na literatura poética, Castro Alves coloca a guitarra nas mãos de Sílvia no "Drama Cômico em Quatro Palavras”, intitulado “Uma página de Escola Realista”. Na pequena alcova, a figura feminina, à “meia voz, acompanhando-se na guitarra”(ALVES, 2005, p. 241), chora no leito de morte de Mário. Por meio de rubricas, o autor indica que "aos últimos arpejos [de Sílvia] cai-lhe uma lágrima (ALVES, 2005, p. 241)”, e “Mário (vendo-a chorar)”, declara:

Sílvia! Deixa rolar sobre a guitarra,

Da lágrima a harmonia peregrina!

Sílvia! Cantando - és a mulher formosa!

Sílvia! Chorando - és a mulher divina!

(ALVES, 2005, p. 241-242).

Neste trecho, é importante observarmos três pontos: o primeiro relacionado à execução do arpejo, através do qual antevê-se metaforicamente a imagem das lágrimas rolando pelo rosto de Sílvia que chora "sobre a guitarra", ou seja, o instrumento transforma-se em seu amparo, seu travesseiro. $\mathrm{O}$ segundo trata-se da beleza e do fascínio despertados por Sílvia ao cantar e tocar a guitarra, encantando seu ouvinte-amante. O terceiro e último aspecto refere-se à "harmonia peregrina" que marca e compóe, em termos históricos, musicais e simbólicos, os caminhos seguidos pelo instrumento. Acompanhando tantos sujeitos errantes (como seresteiros, trovadores, tropeiros, soldados e ciganos), o pinho se revela em sua condição devocional e sua capacidade de viajar por terras longínquas. Essa portabilidade possibilita - e em parte explica - sua enorme difusão, democratização e participação na configuração dos mais variados e importantes estilos e gêneros musicais (como a modinha e o lundu).

Apesar de presa pelos “frios cadeados” dos “brancos dedos” de Mário, Sílvia revela sua ânsia por liberdade, seu desejo transbordante e o nome do verdadeiro homem amado:

\footnotetext{
${ }^{1}$ Trecho do poema: “Ária noturna” do livro “Versos e versões” de Raimundo Correia (1887, p. 38).
} 
Paulo! Vem à meia-noite...

Mário morre! Mário expira!

Vem que minha alma delira

E embalde cativa estou...

(ALVES, 2005, p. 247).

Nesta mescla entre o trágico e o cômico que envolvem as complicadas relaçóes amorosas, a tensão criada pela triangulação amorosa é desfeita com a morte de Mário. Tendo lido clandestinamente a confissão da mulher “cativa”, o sujeito a "libera” para seguir seu caminho (“Sílvia! a morte abre-me os dedos,/ És livre, Sílvia... caminha!”) ( ALVES, 2005, p. 247). Para Sílvia, a liberdade chega pela viuvez.

Se, neste cenário, a guitarra aparece em mãos femininas, o mesmo não se reflete na maioria do material coletado. Esta percepção, no entanto, precisa ser entendida para além do discurso literário que materializa e expóe o senso coletivo que envolve o instrumento. Assim, levando-se em consideração a estruturação dos papéis de gênero na cultura brasileira, notamos que é comum e recorrente a associação do violão ao universo masculino, cabendo à mulher um lugar passivo e distante, enquanto inspiração e/ou interlocutora da manifestação poético-musical.

Neste contexto que nos rememora a prática e a imagem ${ }^{2}$ da seresta, a musa pura (associada à rosa e à flor em botão) é geralmente descrita em estado de adormecimento. Do sono que conduz ao encantamento (em referência ao mítico ou fabular) e também ao entorpecimento do desejo, a mulher é acordada pelos sons que prenunciam a chegada do homem apaixonado.

Já o seresteiro vivifica a suposta relação com a boemia e a vadiagem. Essa figura, inclinada à vida noturna, é visto como adepto das ruas, dos bares e botecos (locais tidos como inadequados à dama). Por outro lado, é também o sujeito à margem, de vida livre - característica considerada perigosa ou mesmo condenável para uma mulher -, pois escapa às convençóes sociais e às obrigaçóes esperadas.

A imagem da seresta revela ainda o duplo predestinação-proibição (em referência à cena do balcão shakespeariano e ao arquétipo do amor juvenil de Romeu e Julieta) marcado pela distância geográfica, física e social entre a musa na sacada, resguardada - cerceada - pela casa, pelos costumes,

\footnotetext{
${ }^{2}$ É importante esclarecermos que as imagens sugeridas se apresentam incompletas e esboçadas, sob a ótica tanto das experiências pessoais, quanto conforme o contexto sociocultural em que o instrumento e o indivíduo estão inseridos. Logo, a evocação das imagens tem relação com a historicidade e com o pacto envolvendo o leitor e os sentidos coletivos culturais.
} 
e pelo patriarcado, e o homem apaixonado, acompanhado por seu instrumento e os estigmas que carregam.

O perigo representado pelo violão/violonista é que, apesar de todas as barreiras, os sons do instrumento ultrapassam os limites e colocam a mulher no dilema de abrir ou não a janela. Sobre este aspecto, Carlos Drummond, no poema "A serenata", reforça: "não há garrucha que impeça:/ A música viola o domicílio e põe rosas no leito da donzela.” (ANDRADE, 1968, p. 24).

Mais do que penetrar os limites geográficos e oníricos, esta violação se estende à figura da mulher. Isto ocorre porque, frequentemente, o violão vadio - véspera do malando -, está associado a mais uma característica importante: a do sedutor. Filiado ao arquétipo donjuanesco, o hedonista e colecionador de amores com seu “violão impudico", influi no universo feminino, despertando desejos, mas também provocando dores e desilusões. Os impactos na figura da mulher que escuta e se rende ao sedutor (a seu chamado e aos seus sons de seu violão) envolve a desilusão, a violação (de sua vida e de seu corpo) e a mácula.

Pelos riscos que apresenta, há um discurso social censor e preventivo para que a donzela feche a janela e escape ao fascínio despertado pelo sedutor. No entanto, as tramelas não impedem o encanto e a nódoa (de rosa em botão à flor despedaçada), levando a mulher que se entrega à fratura, à violação e ao abandono. Vejamos, através da escrita feminina da poetisa (que também estudava o instrumento), folclorista e escritora Cecília Meireles, o que o violão nas mãos de uma mulher revela:

O violão e o vilão

Havia a viola da vila.

A viola e o violão.

Do vilão era a viola.

E da Olivia o violão.

O violão da Olívia dava

vida a vila, a vila dela.

$\mathrm{O}$ violão duvidava

da vida, da viola e dela.

Não vive Olívia na vila.

$\mathrm{Na}$ vila nem na viola.

O vilão levou-lhe a vida,

levando o violão dela. 


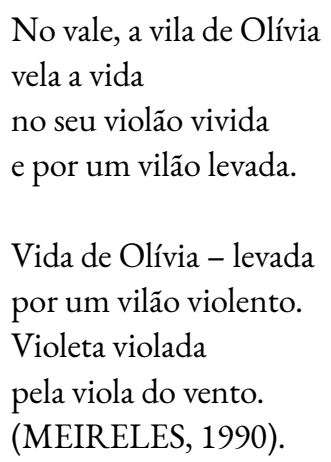

Integrando o livro infantil intitulado "Ou Isto ou aquilo" - última obra da autora publicada no ano de sua morte, em 1964 - o poema, embora se destine às crianças, permite múltiplas interpretaçôes. ${ }^{3}$

“O violão e o vilão” se caracteriza pelo uso de vocabulário simples e corrente, valendo-se de palavras e períodos curtos, ritmo breve e recorrente, aliterações, assonâncias, e rimas que criam um jogo fonético por sua constante repetição. Assim, a comunicação sonora representa um desafio pelo baralhar dos fonemas, funcionando como uma espécie de trava-línguas tão próximo à dinâmica e ao ambiente infantil.

No jogo fonético e semântico, o violão imprime o impulso rítmico-temático do poema, bem como a textura sonora e de sentido. Contudo, não pretendemos aqui nos aprofundar em análises estruturais ou nos aspectos destinados à infância, e sim, em seu sentido para adultos, pelo profundo sentimento que carrega e suscita.

Neste “era-uma-vez” às avessas, não é apresentado ao leitor o nome próprio ou a identidade da figura masculina, cuja referência se dá sob a veste e ampla designação de “vilão”. É claro que, mesmo sem a identificação, seu simbolismo permanece. Já a mulher, no entanto, assume sua individualidade, sem máscaras ou disfarces, e tem seu nome exposto - "Olívia” -, assim como sua história-poesia, suas incertezas, desilusões e dores pela violação sofrida.

No campo das oposiçốes, construído pelo jogo vocabular do discurso, identificamos importantes contraposições referentes - e pertencentes - a cada sujeito: Olívia $\leftrightarrow$ vilão; violão $\leftrightarrow$

\footnotetext{
${ }^{3}$ Sobre as várias possibilidades de leitura, Carlos Drummond de Andrade, em uma crônica publicada no jornal "Correio da Manhâ", em 10 de julho de 1964, declara: "crianças, apenas? Tenho para mim que adultos se encantaram com este livro novo que não é para eles". E conclui, "encontro do pequeno com a poesia: sorte dos garotos que toparem com essa caixa de surpresas. [...] Não sei se passo o livrinho ao pessoal miúdo da minha roda ou se fico com ele para mim" (ANDRADE, 1964, p. 6).
} 
viola; dar $\leftrightarrow$ levar; e violeta $\leftrightarrow$ violento. Nessa conjuntura, a diferença entre os instrumentos é fundamental para o jogo, não podendo ser tomados, portanto, como sinônimos, já que, sem a diferença entre eles, não se estabelece o desafio, a antítese e a violência implícita nesse processo.

Assim, apesar de os substantivos serem de natureza concreta, é possível enxergar neles outras compreensóes, nas quais a viola pode tanto significar o instrumento, quanto ocupar o lugar de verbo. Por esse viés, o ato de violar, atribuído ao vilão, requer do violão um sentido também mais amplo e profundo, adquirindo o significado e a representação não só do corpo, como da vida da mulher.

Se, por um lado, o violão dava vida à vila e à Olívia, por outro, ele também hesitava e duvidava "da vida, da viola e dela”, revelando a insegurança que espreita e intuindo o destino a que a mulher seria lançada. A dor que vem pelas mãos e pelos sons do vilão/viola tira de Olívia/violão a condição de tocar - em ambos os sentidos - a música e o seu corpo.

Esta espécie de aniquilamento simbólico imposto à mulher é marcada pela modificação no fluxo da leitura e na acentuação do texto poético. Com isso, o desfecho da história é tensionado também através da quebra da reiteração fonética pela presença da consoante [t], cuja emissão desvozeada e explosiva reforça a semântica das palavras "violento" e "vento". Esses termos que adjetivam, metaforizam e qualificam a violência dos atos do vilão, também trazem o fonema [v] que, por seu escoamento contínuo do ar, produz um ruído de fricção que perpassa todo o poema. Assim, tanto o vilão (que se associa ao vento que passa), quanto o violão tem seus sons e suas semânticas ampliadas pelo efeito fonético.

Em “O violão e o vilão” não se pode ignorar a experiência da perda, apenas fazê-la tolerável. Ao suportar a dor da vivência, da desilusão e do roubo, sem, contudo, apresentar soluçóes apaziguadoras, resta apenas à mulher, a violação e o abandono. Estes sentimentos nos conectam a percepções coletivas e universais, marcadas pelo desafio do jogo, pelo desencanto e pela noção de transitoriedade e impermanência da vida. Através do violão de Olívia - seu instrumento e metáfora de seu corpo, por forma e associação -, vemos a representação da mulher silenciada. Perdura a dor e a ausência no bojo desta "violeta violada". 


\section{2. "Colhendo raios de lua,/ fazia cordas de prata/ Que, se esticadas, vibravam/ O corpo da mulher nua"}

Se, por um lado, o violão que metaforiza a mulher no discurso feminino deixa transparecer o desejo pela liberdade e a fragmentação do ser pela violação - como na vida de Olívia -, por outro, a vinculação recorrente entre as formas físicas do instrumento e do corpo feminino parece ainda se perpetuar como imagem estereotipada e hiper sexualizada da mulher através dos pactos sociais e coletivos.

Na canção "Violão" do compositor e poeta carioca Paulo César Pinheiro (1949), o instrumento surgiria a partir do "corpo esculpido de uma mulher", em “madeira de pinho", pelas mãos de um artesão. O sujeito masculino que entalha e "colhe" as cordas prateadas, é também quem confere - a partir de si - o coração e o nome ao objeto concebido (em um reconhecimento que se dá pelo poder da linguagem). De maneira análoga à gênese da criação, ${ }^{5}$ o violão teria sua origem quando, "nesta mulher de madeira”, é colocada não a costela, mas sim, o "coração”.

Além de o homem/artífice ocupar, na canção, um papel fundamental na concepção - da mulher e do violão -, podemos identificar a figura feminina envolvida em um traçado de percurso originário (árvore $\rightarrow$ mulher $\rightarrow$ violão). Porém, esse desenho também permite um efeito de justaposição. Ou seja, a imagem da mulher se sobrepóe à do violão, a tal ponto em que se fundem. Esta visão ao mesmo tempo em que traz, obviamente, sentidos poéticos, por vezes pende à objetificação da mulher e ao reforço de determinados padróes que constituem um lugar comum e estereotipado, atravessando tempos e os mais variados meios e discursos.

Esta fusão fica explícita em um texto no qual o diplomata (que também tocava violão) e "poetinha brasileiro" Vinícius de Moraes descreve "Uma Mulher Chamada Guitarra”: 6

\footnotetext{
"Trecho da canção "Violão": "Um dia eu vi numa estrada/ Um arvoredo caído/ Não era um tronco qualquer/ Era madeira de pinho/ E um artesão esculpia/ O corpo de uma mulher/ Depois eu vi/ Pela noite/ O artesão nos caminhos/ Colhendo raios de lua/ Fazia cordas de prata/ Que, se esticadas, vibravam/ O corpo da mulher nua/ E o artesão, finalmente,/ Nesta mulher de madeira,/ Botou o seu coração/ E lhe apertou contra o peito/ E deu-lhe nome bonito/ E assim nasceu o violão”. (COSTA; PINHEIRO, 1993).

5 "E da costela que tinha tomado do homem, o Senhor Deus fez uma mulher, e levou-a para junto do homem".

${ }^{6}$ Este texto integra a coletânea Para Viver um Grande Amor (1962) que engloba, além das crônicas escritas pelo autor carioca para o jornal Última Hora (entre 1959 e 1962), os poemas escritos em Paris, em 1957.
} 
Uma mulher chamada guitarra

Um dia, casualmente, eu disse a um amigo que a guitarra, ou violão, era "a música em forma de mulher". A frase o encantou e ele a andou espalhando como se ela constituísse o que os franceses chamam un mot d'esprit. Pesa-me ponderar que ela não quer ser nada disso; é, melhor, a pura verdade dos fatos.

O violão é não só a música (com todas as suas possibilidades orquestrais latentes) em forma de mulher, como, de todos os instrumentos musicais que se inspiram na forma feminina - viola, violino, bandolim, violoncelo, contrabaixo - o único que representa a mulher ideal: nem grande, nem pequena; de pescoço alongado, ombros redondos e suaves, cintura fina e ancas plenas; cultivada mas sem jactância; relutante em exibir-se, a não ser pela mão daquele a quem ama; atenta e obediente ao seu amado, mas sem perda de caráter e dignidade; e, na intimidade, terna, sábia e apaixonada. Há mulheres-violino, mulheresvioloncelo e até mulheres- contrabaixo.

Mas como recusam-se a estabelecer aquela íntima relação que o violão oferece; como negam-se a se deixar cantar preferindo tornar-se objeto de solos ou partes orquestrais; como respondem mal ao contato dos dedos para se deixar vibrar, em benefício de agentes excitantes como arcos e palhetas, serão sempre preteridas, no final, pelas mulheres-violão, que um homem pode, sempre que quer, ter carinhosamente em seus braços e com ela passar horas de maravilhoso isolamento, sem necessidade, seja de tê-la em posições pouco cristãs, como acontece com os violoncelos, seja de estar obrigatoriamente de pé diante delas, como se dá com os contrabaixos.

Mesmo uma mulher-bandolim (vale dizer: um bandolim), se não encontrar um Jacob pela frente, está roubada. Sua voz é por demais estrídula para que se a suporte além de meia hora. E é nisso que a guitarra, ou violão (vale dizer: a mulher-violão), leva todas as vantagens. Nas mãos de um Segovia, de um Barrios, de um Sanz de la Mazza, de um Bonfá, de um Baden Powell, pode brilhar tão bem em sociedade quanto um violino nas mãos de um Oistrakh ou um violoncelo nas mãos de um Casals. Enquanto que aqueles instrumentos dificilmente poderão atingir a pungência ou a bossa peculiares que um violão pode ter, quer tocado canhestramente por um Jayme Ovalle ou um Manuel Bandeira, quer "passado na cara" por um João Gilberto ou mesmo o crioulo Zé-com-Fome, da Favela do Esqueleto.

Divino, delicioso instrumento que se casa tão bem com o amor e tudo o que, nos instantes mais belos da natureza, induz ao maravilhoso abandono! E não é à toa que um dos seus mais antigos ascendentes se chama viola d'amore, como a prenunciar o doce fenômeno de tantos coraçóes diariamente feridos pelo melodioso acento de suas cordas... Até na maneira de ser tocado - contra o peito - lembra a mulher que se aninha nos braços do seu amado e, sem dizer-lhe nada, parece suplicar com beijos e carinhos que ele a tome toda, façaa vibrar no mais fundo de si mesma, e a ame acima de tudo, pois do contrário ela não poderá ser nunca totalmente sua.

Ponha-se num céu alto uma Lua tranquila. Pede ela um contrabaixo? Nunca! Um violoncelo? Talvez, mas só se por trás dele houvesse um Casals. Um bandolim? Nem por sombra! Um bandolim, com seu tremolos, lhe perturbaria o luminoso êxtase. E o que pede então (direis) uma Lua tranqüila num céu alto? E eu vos responderei: um violão. Pois dentre os instrumentos musicais criados pela mão do homem, só o violão é capaz de ouvir e de entender a Lua. (MORAES, 1962, p. 7-8, grifos nossos).

Na relação com o feminino e no desejo "pelas mulheres-violão, que um homem pode, sempre que quer, ter carinhosamente em seus braços" (MORAES, 1962, p. 7), cria-se um ponto de contato entre a mulher e o instrumento que, apesar de lírico, aponta para a objetificação da figura feminina. 
Isto se dá tanto pelo imperativo masculino (reafirmando a submissão da mulher "atenta e obediente ao seu amado”), quanto pela associação entre as formas - "o único que representa a mulher ideal: nem grande, nem pequena; de pescoço alongado, ombros redondos e suaves, cintura fina e ancas plena (...)”. (MORAES, 1962, p. 7).

Essa colagem ou unificação também acontece através das sugestôes metafóricas do corpo e dos efeitos causados pelo toque masculino no violão e na mulher - ambos aninhados "nos braços de seu amado”. Assim, ao tocar ou ferir o violão, o homem realizaria, por metáfora e extensão simbólica, o toque físico no corpo feminino. ${ }^{7}$

Todos estes aspectos expõem as expectativas e determinações de padrão físico e de comportamento, reforçando antigas estruturas nas quais se espera da mulher a manutenção do “caráter e dignidade" frente à sociedade; e, a subserviência "na intimidade”, agindo como "terna, sábia e apaixonada”.

Esta feminilidade ambivalente que reúne "uma dita superioridade espiritual das mulheres com a submissão e passividade frente a desejos e ordens dos homens”, está impregnada de um modelo aceitável e controlado de conduta. Assim, passa-se a buscar uma referenciação exemplar de "mulher, mãe, esposa, amante, profissional bem-sucedida, portadora (mas não dona) de um corpo cultivado dentro dos padrões ditados diariamente”. (ROSA; NOGUEIRA, 2015). Neste processo, além do desejo de aprovação, a validação da mulher está condicionada à aprovação de um homem, "seja pai, marido, professor ou colega”, de maneira que também "não se torne uma ameaça para a comunidade feminina”. Conforme Rosa e Nogueira (2015):

Este desejo de aprovação com o qual a construção da identidade feminina lida, de forma ao mesmo tempo declarada e subliminar, traveste-se, na cultura ocidental, de uma aura de 'a forma como apenas as coisas devem ser', revestindo-se de uma crueldade ditatorial que afeta diretamente o estar no mundo para a imensa maioria das mulheres. (ROSA; NOGUEIRA, 2015, p. 50)

\footnotetext{
${ }^{7}$ As figuras de linguagem relacionadas à sensualidade e à sexualidade também ocorrem em diversas obras pertencentes a diferentes momentos históricos, como o D. Juan de Castro Alves que, no poema "Os três amores", dirige-se a todas as mulheres que foram por ele seduzidas, exclamando: “Donzelas amorosas"/ "Vós conheceis-me os trenos na viola!”. Além da realização sexual sugerida pelo verso, a viola pode representar o corpo feminino tanto em uma perspectiva mais ampla, - afinal as donzelas sabem e conhecem as habilidades do sedutor -, quanto o toque na região íntima. Essa conotação erotizada, representando não só o ato sexual, como o corpo feminino, acontece também em Gregório de Matos que, ao falar de "Anica", sem os véus românticos e pondo-lhe "a viola em cacos", revela a conotação sexual do encontro, "já que fui tão desgraçado,/que buli co'a escaravelha,/ e toquei sobre o buraco" (MATOS, 1992).
} 
É importante notar ainda, retornado à Vinícius de Moraes, que o texto faz referência não só a importantes intérpretes do violão da música erudita (como Segovia, Barrios, e Sanz de la Mazza), como da esfera popular (Bonfá, Baden Powell, João Gilberto, Jaime Ovalle). São incluídos também os apreciadores do instrumento e os sujeitos à margem (como o crioulo Zé-com-Fome, da Favela do Esqueleto). Além da paixão pelo violão, o que os une, é também o fato de serem todos homens.

Apesar de neste trecho transparecer a capacidade do instrumento de perpassar fronteiras, acomodar os mais variados gêneros musicais, ser praticado pelas mais modestas ou habilidosas mãos, e, sem dúvida percorrer nomes marcantes da história do violão, a prevalência masculina expóe a ausência da referenciação feminina.

É claro que reconhecemos que as características e os nomes citados servem ao texto, e respeitamos a liberdade expressiva, sem buscar precisões históricas ou musicológicas. No entanto, é importante considerar que a ambiguidade do discurso literário e cultural em relação à própria trajetória do instrumento pode suscitar questôes mais amplas. Por este viés, as narrativas dominantes se distanciam da grande abrangência que, historicamente, o violão alcançou entre as mulheres, sendo tocado tanto no ambiente doméstico e nas estudantinas, quanto contando com importantes intérpretes e solistas. Inclusive seria, não por acaso, que as mãos femininas contribuiriam para que o violão tivesse seus estigmas suavizados e revistos.

\section{3. "Mãos de fada, sim"8}

Ao longo da história do violão no Brasil, diversas mulheres corroboraram para a consolidação e disseminação do instrumento, marcando presença na performance, no ensino, nas gravações, na produção composicional e na ressignificação dos estigmas associados ao violão. Reconhecendo a importância, mas também a impossibilidade de, neste artigo, abarcar toda a potência, os desdobramentos e a amplitude de tantas mulheres violonistas que fizeram - e fazem parte - do

\footnotetext{
8 "Mãos de fada, sim, que só mesmo de fada podem ser as mãos que seguram a fragilidade daquele violão magnífico e lhe vão ao fundo d’alma, e lhe arrancam uma sonoridade feita de luz de luar, e fazem que essa sonoridade se espelhe pelo ambiente, perfumando-o de uma suavíssima poesia, e penetre no coração de quem à escuta, elevando-o numa dulcíssima carícia. Está-se a ver que a artista que tanto alcança é uma artista perfeita. E Josefina Robledo o é, pela técnica vertiginosa, que lhe permite dominar, em absoluto esse instrumento que é um dos mais difíceis que existem". (O REBATE, 1918 apud PORTO; NOGUEIRA, 2007, p. 7).
} 
decurso violonístico no Brasil, optamos por citar apenas alguns nomes e nos direcionarmos às mudanças discursivas e simbólicas relacionadas ao instrumento.

Nas primeiras décadas do século XX, a profunda segregação sociocultural e as associaçôes negativas que marcaram o violão, avultaram os empecilhos para aceitação do instrumento na esfera erudita. O Jornal do Commercio (1916) aponta que os esforços para essa inclusão teriam sido em vão até aquele momento, pois mesmo "quando algum virtuosi quer dele [o violão] tirar efeitos mais elevados na arte dos sons, jamais consegue o objetivo desejado, ou mesmo resultado seriamente apreciado” (JORNAL DO COMMERCIO, 1916 apud TABORDA, 2004, p. 63).

A modificação da cena violonística - tanto em termos de função (incorporando também sua faceta como solista), quanto das significações que acompanhavam o instrumento - envolveria a contribuição e o pioneirismo, ainda que discreto, de alguns violonistas brasileiros, e a vinda de concertistas, principalmente do paraguaio Augustín Barrios (1885-1944) e da espanhola Josefina Robledo (1892-1972). Esse processo aparece retratado em uma crítica do jornal O Estado de São Paulo (1917 apud ANTUNES, 2002, p. 43) ao documentar que “(...) modernamente [o violão], começa a reabilitar os seus créditos, já interessa os círculos artísticos e documenta nos grandes salóes as suas qualidades de instrumento aristocrático”.

Neste contexto, a figura feminina da espanhola Josefina Robledo (1892-1972) ${ }^{9}$ causaria certo impacto no meio e no imaginário relacionado ao instrumento. $\mathrm{O}$ discurso construído a partir da perspectiva do violão nas mãos de uma mulher viria envolto pelo encanto fabular, da lua e do coração, da doçura e da delicadeza. Com isso, é possível inferir que essas metáforas e associaçôes, contribuiriam, ou pelo menos, atuariam no deslocamento dos sentidos tão vinculados ao masculino (como a utilização do instrumento para seduzir e "corromper" as musas nas serenatas e os próprios ambientes frequentados, incluindo as ruas e os bares).

Ao rever esses sentidos e contrabalancear as duas esferas - a elegância e delicadeza relacionadas à figura mulher e o estigma e desapreço pelo violão-violonista -, Robledo influiria no processo de ressignificação do instrumento: "Vê-se então que os dedos finos de sua mão aristocrática, parecem

\footnotetext{
${ }^{9}$ Robledo foi aluna do compositor e violonista Francisco Tárrega (1852- 1909), considerado o fundador da escola moderna de violão. A instrumentista espanhola morou no Brasil e seu trabalho como educadora modificou não só a perspectiva e a formação dos violonistas brasileiros, como também ampliou as possibilidades musicais e técnicas da época, "prodigalizando sábios ensinamentos às moças da alta sociedade e rapazes de real mérito". Através dela "o violão se infiltrou nas altas camadas sociais de São Paulo e é cultivado com enorme carinho.” (PISTORESI et al., 1929, p. 24).
} 
asas que farfalham e adejam, comunicando hino de amor e emoções de vida, nas cordas de um instrumento vulgar, que ela nobilita...” (...) (O REBATE, 1918 apud PORTO; NOGUEIRA, 2007, p. 7).

É preciso esclarecer que esta trajetória de redefinição e aceitação do violão no contexto da música erudita envolveria muitos outros aspectos, como a ampliação do repertório solista, a criação de arranjos e transcrições de obras consagradas, a difusão da técnica moderna e a realização de apresentaçốes em salas de concerto (principalmente no Rio de Janeiro e em São Paulo). No entanto, ao considerar que nas mãos de Robledo o violão "deixa de ser um instrumento subalterno, perde a qualidade de simples acompanhador de modinhas e apresenta-se transfigurado, falando à nossa sensibilidade e às nossas emoções.” (JORNAL DO COMMERCIO, 1917 apud TABORDA, 2004, p. 68), podemos pensar na força representativa que a violonista teria no imbricado processo para equidade do instrumento no panorama musical. Apesar dos preconceitos que ainda permaneciam arraigados ao instrumento, a crítica jornalística reforça:

É preciso insistir neste ponto: o instrumento da sra. Robledo não se parece em coisa nenhuma com o violão popular, das serenatas e troças, dos bailaricos e 'assustados'. Para todas as coisas deste mundo se estabelecem uma hierarquia e não há um só recanto da vida onde se não possa encontrá-la. No que respeita ao mundo musical bastará dizer que o 'virtuosismo' achou no violão uma alma e conseguiu elevá-la ao nível em que se acham hoje as dos mais aristocráticos instrumentos. E de como o domínio absoluto desse instrumento é tanto ou mais difícil que o do piano, violino ou violoncelo, di-lo eloqüentemente o limitadíssimo número dos seus executantes. (O ESTADO DE SÃO PAULO, 1917 apud ANTUNES, 2002, p. 46).

Entre "ingrato" instrumento de "noctâmbulos e serenatistas" (do início do século XX) e o seu cultivo "com enorme carinho", o violão atinge grande abrangência na prática feminina marcando "presença nas agrupaçốes sócio-familiares das estudantinas, onde moças e rapazes da sociedade tocavam o violão, ao lado de bandolins e mandolas”. (PORTO; NOGUEIRA, 2007, p. 4).

O instrumento também alcançaria enorme sucesso nas mãos e no cotidiano das moças de "boa família”, movimentando, assim, o ambiente carioca no final dos anos 20. Isso ocorreria através das jovens senhoritas da sociedade que, dedicadas ao estudo do instrumento, cantavam e tocavam um repertório de canções brasileiras. Para Taborda (2011), essa atitude revelava não só a retomada do “regionalismo" como "o envolvimento dessas mulheres refletia a legítima aspiração à cidadania, e 
sobretudo os sentimentos e inovaçóes abrigado pela 'vida moderna' (...)” (TABORDA, 2011 p. 157):

\begin{abstract}
Em fins dos anos 1920, surgiu uma novidade no ambiente violonístico carioca que ecoou nas principais capitais brasileiras: jovens senhoritas da sociedade dedicaram-se ao instrumento, levando para o público um repertório de cançốes típicas brasileiras. Consagrado ainda pela fundação de clubes e sociedades para a prática do violão, o movimento viria englobar a união de duas tendências que marcaram fortemente o modernismo brasileiro; por um lado representava a retomada da linha regionalista e nacionalista refletida na criteriosa seleção do repertório; por outro, consagrava a manifestação de cosmopolitismo simbolizada pela presença de mulheres jovens, bonitas e independentes. (TABORDA, 2011, p. 154).
\end{abstract}

A autora também aponta para prevalência do canto acompanhado ao violão, sendo executado através de arranjos mais simples. Embora essas especificidades do repertório tendam a uma prática mais comumente adotada, a atividade violonística representaria, ainda conforme Taborda (2011), uma inovação e uma ousadia para época, posto que, nesse período, caberia às mulheres a formação professoral e as tarefas do lar: "Neste contexto, aprender violão significava mais que estudar música, era uma tomada de atitude. Apresentá-lo em audiçôes públicas, lançar-se além dos domínios doméstico e até, possivelmente, abraçar uma profissão significava mais ainda: uma afronta, um desafio.” (TABORDA, 2011, p. 156).

É preciso considerar, entretanto, que a irradiação dos instrumentos de cordas dedilhadas no contexto feminino seria datado de um período bem anterior, marcando desde o início do século XIX, não um movimento de autonomia e transgressão, mas sim, a reiteração dos papeis sociais conferidos às mulheres. Por esse viés, o violão estaria entre as “prendas” requeridas, e através da qual seria possível sobressair-se cultural e socialmente, sobretudo nos espaços chancelados para o convívio (como os saraus).

Sobre este aspecto, em raros casos a atividade musical se transformava em carreira profissional. Como o aprendizado musical fazia parte da educação feminina, enquanto obrigação, independia da vontade e da aptidão das moças. Sem intentar a formação como musicista, a prática instrumental servia ao entretenimento, à ornamentação das reunióes sociais, ou mesmo, "ao pequeno espaço de tempo que mediava entre a vida da menina e da senhora": período em "que a moça entregava-se ao aprendizado da música e das maneiras, ao interesse pelos vestidos, vivendo na expectativa da chegada do marido”. (SOUZA, 1987, p. 89 apud CARVALHO, 2012, p. 39). 
Por outro lado, é também possível pensar que a escolha pelo violão carregasse algo de transgressor principalmente em relação aos estigmas que o definiam e se colocado frente ao piano, instrumento preferido para a educação das moças por ser, na época, símbolo de status social e refinamento cultural. Porto e Nogueira (2007) reforçam que,

A associação das mulheres à um instrumento ainda razoavelmente desconhecido, socialmente menos considerado que o piano; mas ao mesmo tempo transgressor, moderno e revolucionário, pode trazer em si o desejo de associação à imagem de instrumento maldito. No entanto, pode encerrar também o desejo de redenção do instrumento através de sua prática. Prática feminina, bem considerada socialmente, que traria novos significados ao instrumento através de sua associação. (PORTO; NOGUEIRA, 2007, p. 4).

Afora poucas exceçôes documentadas, como Josefina Robledo (que era estrangeira), Nair de Teffé ${ }^{10}$ e Maristela Kubitschek, ${ }^{11}$ a maioria absoluta dessas mulheres encerrava a carreira musical com o matrimônio (como a violonista Paquita Baylina). ${ }^{12}$

A inserção da mulher no cenário violonístico brasileiro não aconteceria de maneira linear, encontrando-se ainda em processo de estudo, pesquisa e atualização. Dele fazem parte nomes como o da violonista e cantora Olga Praguer Coelho (1909-2008), expoente entre as décadas de 1930 e 1960; Monina Távora (1921-2011) que, apesar de estrangeira, morou no Brasil por mais de 30 anos e lecionou para importantes nomes do violão brasileiro; e Maria Lívia São Marcos (1942), filha do violonista Manoel São Marcos que, tendo sua iniciação musical ainda muito cedo, realizou inúmeros recitais no país e estabeleceu sua carreira internacional na década de 1960.

A segunda metade do século XX é também marcada por um grande número de mulheres tocando o instrumento, como ilustrado pela revista Violão e Mestres n. 5, publicada em 1966. Esse periódico comenta o sucesso de um conjunto musical formado apenas por mulheres denominado "As princesas do violão” e coordenado pela professora Julieta Corrêa Antunes. ${ }^{13}$ Valendo-se de referências

\footnotetext{
${ }^{10}$ Nair de Teffé - a primeira-dama, casada com o presidente Hermes da Fonseca - além de estudar violão, manteve certo convívio com compositores populares, como Catulo da Paixão Cearense.

${ }^{11}$ Maristela Kubitschek, filha do então Presidente da República Juscelino Kubitschek, foi aluna do violonista Dilermando Reis.

${ }^{12}$ Paquita Baylina, musicista gaúcha, estudou com o cego Levino Albano da Conceição, porém interrompeu suas atividades musicais ao se casar, em 1923.

${ }^{13}$ Conforme entrevista para a revista, a professora Julieta, além de achar "que o violão foi feito para a mulher e desde cedo se dedicou a ele", também "faz parte dos que acreditam que saber acompanhar o canto é disciplina essencial na formação de bom violonista.” (ANTUNES, 1966, p. 22).
} 
românticas para dar nome ao conjunto, este registro (Fig. 1) nos traz uma quantidade numerosa de mulheres tocando violão, ocupando os espaços para além da casa, e se estabelecendo nos palcos.

FIGURA 1 - "As princesas em noite de gala”- Foto ilustrativa das mulheres violonistas

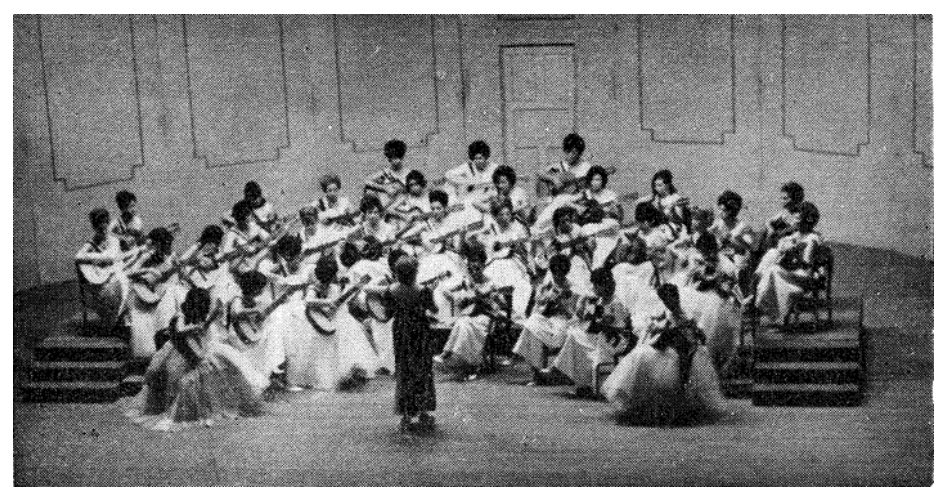

Fonte: VIOLÃO E MESTRES № 5, 1966, p. 23.

Outras muitas mulheres influenciaram e participaram de maneira definitiva na construção da história do violão no Brasil. Essa força feminina, é claro, tem uma amplitude muito maior, fazendose presente no violão da América Latina, na Europa, e em todo mundo. Ela emerge e se atualiza, rompendo mecanismos velados (ou não) de apagamentos históricos.

No recorte proposto por este trabalho, vemos que mesmo diante da predominância da voz masculina, a presença feminina - apesar do silenciamento imposto - se manifesta não de forma passiva (apenas como inspiração, tema, ou objeto de conquista e desejo), mas atuando efetivamente no meio violonístico.

\section{Considerações finais}

Estudar as associações entre a mulher e o violão a partir do discurso literário e cultural brasileiro, apontou para a convivência de polaridades marcadas tanto pela representação de delicadeza, enlevo e pureza relacionadas à figura feminina, quanto de volúpia, sexualidade e sensualidade no imaginário de seu corpo.

Entre enaltecida e seduzida, o discurso constrói e revela a mulher pelo viés da inspiração e recepção do gesto poético-musical. Entretanto, o violão que aparece no dedilhar dos sentimentos e desejos de Sílvia, na tristeza e desencanto de Olívia, nas mãos de tantas mulheres e de grandes 
intérpretes da história do instrumento, escapa à fragilidade e às expectativas estereotipadas, revelando uma potência tantas vezes abafada pelo discurso e pelas imposiçóes culturais.

Do material literário pesquisado, tornou-se notável a quantidade significativamente menor tanto de obras escritas por mulheres, quanto da abordagem da figura feminina tocando o instrumento. A partir desta constatação é preciso ressaltar dois pontos fundamentais: o primeiro, relacionado à autoria feminina, uma vez que, dentro cânone literário, poucas são as mulheres que incluem o violão em sua escrita.

Sobre este aspecto, precisamos levar em consideração que, em termos quantitativos, a desigualdade de gêneros também é perceptível na produção literária, e "essa independe do recorte temporal estabelecido". Como "foi permitido ao masculino narrar" desde os primeiros textos produzidos, "então foi pela exclusão que ao feminino foi proibido ou silenciado o poder da narrativa literária”. (LORD, 2018, p. 132). Atuando como legitimador desta dominação, a reprodução dessas discrepâncias não só reforça as escolhas dos sujeitos que constroem a narrativa e lhe atribuem significados, como pressupõe a exclusão da autoria feminina e seus modos de fazer.

O que se nota, no entanto, é que apesar de escasso, este material não é apático. Pelo contrário, demonstra a inquietude, o ímpeto libertário e os subterfúgios encontrados pelas mulheres para a realização de seus desejos. $\mathrm{Na}$ apropriação da escrita (e também do violão) vemos o feminino contestando os processos que esmaecem suas subjetividades e dissipam suas expressóes. A mulher segue rompendo os limites impostos e galgando fugas dos papéis que lhe são esperados.

O segundo ponto, trata-se dos poucos registros do violão (ou guitarra) em mãos femininas na literatura brasileira. No contato com uma realidade inventada ou não, a imagem que prevalece no discurso literário reforça o imaginário masculino que permeia o violão e não reflete a importância e força feminina para o instrumento - ainda pouco documentada também na própria trajetória histórica do violão. Esta é uma observação relevante, pois, apesar da presença de mulheres violonistas (incluindo o ofício trovadoresco, a abrangência alcançada pelo violão entre as jovens senhoritas, as muitas concertistas e intérpretes nos mais variados espaços e tempos), essas atuações raramente apareceram refletidas nas expressões literárias e nos discursos culturais.

Assim, se, por um lado, a escassez revela a importância da voz ativa e inquieta, por outro, a ausência de registros nos mostra um silenciamento (ou o confinamento) das expressividades e os 
mecanismos de restrição às liberdades femininas.

"Esta espécie ainda envergonhada” vai além da imagem lívida e pura da donzela, para, em meio a conflitos, dualidades e imposições, “carregar bandeira” e assumir seus desejos (PRADO, 1995, p. 11). A mulher abre a janela, faz versos e, ao aceitar "os subterfúgios que me cabem,/ sem precisar mentir" (PRADO, 1995, p. 11), foge do confinamento sociocultural a que historicamente foi submetida. Agora a musa protegida e idealizada da serenata, é também a que exerce sua liberdade e expressividade ao violão, no interior da casa, e também nos palcos.

Neste caminho, é preciso buscar uma “escuta das margens”, rever os limites, abrir as fronteiras para permitir e reconhecer a alteridade e a diferença, mover as tradiçôes de dominação e reparar os silenciamentos. A partir da noção de alijamento do feminino no cânone - violonístico, musical e literário -, tona-se necessário refutar a "hegemonia que não nos pauta, não nos contempla, não nos representa, [...] que nega e exclui a existência das mulheres enquanto criadoras, pensadoras, pessoas. O que se configura numa verdadeira tentativa de extermínio de seus feitos e de sua existência.” (ROSA; NOGUEIRA, 2015, p. 26).

Apesar deste "cargo muito pesado pra mulher", é preciso perceber que a prática violonística não se trata de uma "prenda", um atributo, ou mesmo uma concessão. E sim, um a expressão ativa, pulsante e resistente durante um longo período de apagamento. Neste sentido, torna-se ainda necessário que a voz e os sons femininos ganhem ecos e reverberaçóes, fazendo emergir outras muitas mulheres no meio violonístico que ainda permanecem anônimas.

Por fim, além do incentivo à pesquisa histórica e às iniciativas que promovam a divulgação e o trabalho de mulheres violonistas, é importante a contínua discussão sobre as perspectivas estereotipadas que recaem sobre a esfera do feminino. Isto implica em deslocar as leituras e interpretaçóes, reescrever a história, reformular a análise histórica, revisar os conteúdos existentes, romper com antigas estruturas e imposições, "e voltar às instâncias do saber marginal, do saber esquecido, o das mulheres, presentes - ausentes no plano de subjetividade histórica e no processo de sua humanização.” (TEDESCHI, 2014, p. 25).

Assim, acreditamos ser fundamental a desarticulação de certos costumes cerceadores e o deslocamento de pactos coletivos, para que estas imagens, cristalizadas pelo tempo e pela cultura, possam ser revistas e redesenhadas. 


\section{REFERÊNCIAS}

ALVES, Castro. Espumas Flutuantes. Apresentação e notas José de Paula Ramos Júnior; ilustrações Moa Simplício. 5. ed. Cotia (SP): Ateliê editorial, 2005.

ANDRADE, Carlos Drummond de. Boitempo \& A falta que ama. Rio de Janeiro: Sabiá, 1968. ANDRADE, Carlos Drummond de. Imagens de flautinha. Ou isto ou aquilo. Correio da Manhâ, Rio de Janeiro, 10 jul. 1964.

ARAÚJO, Jorge de Souza. Do penhor à pena: estudos do mito de Don Juan, desdobramentos e equivalências. Salvador: Editus, 2005. 484p.

CARVALHO, Dalila Vasconcellos de. O Gênero da Música: A construção social da vocação. São Paulo, Alameda, 2012.

CASTAGNA, Paulo; ANTUNES, Gilson. 1916: o violão brasileiro já é uma arte. Cultura Vozes, São Paulo, ano 88, v. 88, n.1, p. 37-51, jan./fev. 1994.

CORREIA, Raimundo. Versos e versóes. Rio de Janeiro : Typ. e Lith. Moreira Maximino \& C 1887. Disponível em: https://digital.bbm.usp.br/handle/bbm/5032. Acesso em: 06 jun. 2019.

COSTA, Sueli; PINHEIRO, Paulo César. Violão. In: GUEDES, Fátima. Pra bom entendedor. Rio de Janeiro: Velas, 1993. (CD)

GARCIA, Cláudia A. Amores, volúpias e memórias: um retrato do violão na poesia brasileira. Tese (Doutorado) - Pontifícia Universidade Católica de Minas Gerais. Programa de Pós-Graduação em Letras. 280f. 2019.

LORD, Lúcio José Dutra, Desigualdade de gênero e literatura brasileira: um olhar a partir da Sociologia. Revista Entrelaces, v. 1, no 14, Out.-Dez, 2018.

MATOS, Gregório de. Obra Poética. Rio de Janeiro: Editora Record, 1992. Disponível em: $<$ http://www.literaturabrasileira.ufsc.br/documentos/?action=download\&amp;id=36506>. Acesso em: 1ㅇar. 2019.

MEIRELES, Cecília. Ou isto ou aquilo. Ilustrações de Fernando Correia Dias. Rio de Janeiro: Editora Nova Fronteira; FNDE/MEC, 1990. Disponível em:

$<$ https://www.revistaprosaversoearte.com/cecilia-meireles-poesia-para-criancas/>. Acesso em: 15 out. 2017.

MORAES, Vinicius de. Para viver um grande amor (crônicas e poemas). Rio de Janeiro: Editora do Autor, 1962.

PISTORESI, Aristodemo; PISTORESI, Francisco; SOARES, Oswaldo; DAUMERIE, Yonne. O violão em S. Paulo. $O$ violão, Rio de Janeiro, ano 1, n. 2, 1929.

PORTO, Patrícia Pereira; NOGUEIRA, Isabel Porto. Imagem e representação em mulheres violonistas: algumas reflexões sobre Josefina Robledo. In: CONGRESSO DA ASSOCIAÇÃO NACIONAL DE PESQUISA E PÓS-GRADUAÇÃO EM MÚSICA (ANPPOM), XVII, São Paulo, Anais... 2007. p. 1-12. 
ROSA, Laila; NOGUEIRA, Isabel. O que nos move, o que nos dobra, o que nos instiga: notas sobre epistemologias feministas, processos criativos, educação e possibilidades transgressoras em música. Revista Vórtex, Curitiba, v.3, n.2, 2015, p.25-56

SCOTT, Joan. Gènero y História. México: FCE, Universidad Autonoma de la Ciudad de México,2008.

TABORDA, Marcia Ermelindo. Violâo e identidade nacional: Rio de Janeiro 1830/1930. 2004. 228f. Tese (Doutorado em História Social) - Universidade Federal do Rio de Janeiro, Rio de Janeiro, 2004.

TEDESCHI, Losandro Antonio. Alguns apontamentos sobre história oral, gênero e história das mulheres. Dourados-MS: UFGD, 2014.

TEDESCHI, Losandro Antonio. Os lugares da História Oral e da Memória nos Estudos de Gênero. OPSIS, Catalão, v. 15, n. 2, p. 330-343, 2015

TINHORÃO, José Ramos. As origens da cançâo urbana. São Paulo: Editora 34, 2011.

VIOLÃO E MESTRES N. 5, São Paulo: Violóes Giannini S/A,1964. p. 23

\section{SOBRE A AUTORA}

É doutora em Letras pela PUC Minas e mestra em Performance Musical pela Universidade Federal de Minas Gerais. Possui Pós-graduação em Princípios e Recursos Pedagógicos em Música pela Universidade do Estado de Minas Gerais e Bacharelado em Violão pela mesma instituição. Como professora, atuou no Conservatório Estadual de Música Padre José Maria Xavier e no Centro de Formação Artística e Técnica da Fundação Clóvis Salgado. Desde 2005, leciona na Escola de Música da Universidade do Estado de Minas Gerais, onde integra o quadro docente efetivo. Além de solista e camerista, tem se dedicado à pesquisa nas áreas de performance musical, violão, literatura e canção de câmara brasileira. ORCID: https://orcid.org/0000-0002-0990-807X. E-mail: claudia.violao@gmail.com e claudia.garcia@uemg.br 